A N N A LE S

UNIVER S T A T IS MARIAE CURIE-SKŁODOW S A LUBLIN - POLONIA

VOL. XXIX, 3

SECTIO J

2016

Centrum Edukacji Artystycznej

\title{
URSZULA BISSINGER-ĆWIERZ
}

bissinger@cea.art.pl

\section{Poradnictwo psychologiczno-pedagogiczne szkolnictwa artystycznego forma wsparcia uczniów zdolnych}

Psychological and educational counselling for artistic schools

form of support for gifted students

\section{STRESZCZENIE}

Istotną formą wsparcia psychologicznego uzdolnionych kierunkowo uczniów szkół muzycznych, plastycznych i baletowych jest specjalistyczne poradnictwo psychologiczno-pedagogiczne Centrum Edukacji Artystycznej. Formą pomocy pośredniej są z jednej strony działania informacyjno-szkoleniowe i publikacyjno-badawcze podejmowane z myślą o rodzicach i nauczycielach, a z drugiej strony działania integracyjno-superwizyjne ukierunkowane na wspomaganie zawodowe psychologów i pedagogów szkolnictwa artystycznego. Natomiast działalność poradniana stanowi formę bezpośredniej pomocy uczniom w rozwiązywaniu specyficznych dla szkolnictwa artystycznego problemów dotyczących: radzenia sobie z tremą, efektywnego ćwiczenia gry na instrumencie, czynników demotywujących i motywujących do rozwoju artystycznego, zasobów osobowościowych i samooceny oraz relacji interpersonalnych uczeń-nauczyciel. Problemy dostrzeżone dzięki praktyce poradnianej zaprezentowane zostały w szerokim kontekście rozważań teoretycznych obecnych w polskiej i zagranicznej literaturze przedmiotu.

Słowa kluczowe: poradnictwo CEA; szkoły muzyczne; plastyczne i baletowe; problemy psychopedagogiczne kształcenia artystycznego

\section{WPROWADZENIE}

Od lat 50. ubiegłego wieku podejmowano różne próby organizowania poradni psychologicznych dla szkół artystycznych. Uzasadnieniem tych działań były liczne problemy psychologiczne doświadczane przez uczniów zdolnych, a wyni- 
kające ze specyfiki kształcenia artystycznego (Manturzewska i in. 2010, s. 11-12). W roku 1956 z inicjatywy dwóch profesorów z dziedziny muzyki i psychologii - Stefana Śledzińskiego i Stefana Szumana - powołano przy Centralnym Ośrodku Pedagogicznym Szkolnictwa Artystycznego (COPSA) pierwszą komórkę psychologii muzyki w celu rozwijania prac naukowo-badawczych i rozwiązywania problemów psychologicznych polskiego szkolnictwa muzycznego. Oficjalna współpraca COPSA z Pracownią Psychometryczną PAN i jej ówczesnym kierownikiem Mieczysławem Chojnowskim przyniosła efekty w postaci sprowadzenia z zagranicy standaryzowanych testów zdolności i osiągnięć muzycznych. Powołany w 1957 roku przy COPSA Międzyuczelniany Zespół ds. Badania Zdolności Muzycznych, którego kierownikiem została prof. Maria Manturzewska, dokonał na polskiej populacji adaptacji i normalizacji testów Releigha M. Drake'a, Stephena E. Farnuma i Herberta D. Winga. W tym również czasie powstała na prawach eksperymentu pierwsza poradnia psychologiczna dla szkół muzycznych w Warszawie prowadzona przez Manturzewską (1999). W latach 60. tworzone były nowe poradnie przy szkołach muzycznych, organizowano również seminaria i konferencje psychologiczne dla nauczycieli-muzyków. Na przełomie lat 60. i 70. pod kierunkiem Manturzewskiej został zrealizowany program badawczy nad psychologicznymi wyznacznikami powodzenia w studiach muzycznych. Niestety, z powodu m.in. braku formalnego nadzoru merytorycznego ze strony COPSA, w latach 70. zaczęła zanikać sieć poradni psychologicznych. Dopiero od 2008 roku Centrum Edukacji Artystycznej (CEA) jako specjalistyczna jednostka nadzoru pedagogicznego nad publicznymi i niepublicznymi szkołami i placówkami artystycznymi stopniowo reaktywuje ideę specjalistycznej pomocy psychologicznej dla szkolnictwa artystycznego. Początkowo utworzono trzy punkty konsultacyjne poradnictwa psychologicznego wykonujące zadania na rzecz szkół muzycznych. Natomiast od roku 2011 podejmuje się systemowe działania na rzecz rozwoju poradnictwa dla wszystkich typów szkół artystycznych. Aktualny model profesjonalnej opieki psychologiczno-pedagogicznej nad uczniami szkół muzycznych, plastycznych i baletowych jest unikalny w skali europejskiej. Trzon tego modelu stanowią Specjalistyczne Poradnie Psychologiczno-Pedagogiczne Centrum Edukacji Artystycznej (SPPP CEA).

\section{DZIAŁALNOŚĆ SPECJALISTYCZNYCH PORADNI PSYCHOLOGICZNO-PEDAGOGICZNYCH CEA}

Podstawą prawną działalności SPPP CEA jest Zarządzenie nr 3/2015 Dyrektora Centrum Edukacji Artystycznej w sprawie utworzenia Specjalistycznych Poradni Psychologiczno-Pedagogicznych $C E A^{1}$. Poradnie wchodzą w skład struktu-

${ }^{1}$ Zarządzenie dostępne jest na stronie: www.cea.art.pl/poradnictwo-psychologiczno-pedagogiczne. 
ry organizacyjnej CEA. Nadzór merytoryczny i finansowy sprawuje nad nimi dyrektor Centrum Edukacji Artystycznej, natomiast wizytator ds. poradnictwa psychologiczno-pedagogicznego odpowiada za organizację i funkcjonowanie poradni CEA w poszczególnych regionach. Zadania poradni wykonują psycholodzy CEA, którzy jednocześnie zatrudnieni są w szkolnictwie artystycznym na stanowisku psychologa szkolnego. Wymóg ten podyktowany jest troską o zapewnienie adekwatnej pomocy psychologiczno-pedagogicznej przez specjalistów, którzy dobrze znają specyfikę codziennych problemów uczniów, nauczycieli i rodziców. Poradnie zlokalizowane są w szkołach i placówkach prowadzonych przez Ministra Kultury i Dziedzictwa Narodowego. W roku szkolnym 2014/2015 działało osiem SPPP CEA w: Bydgoszczy, Lublinie, Warszawie, Gdańsku, Zduńskiej Woli, Kielcach, Białymstoku i Poznaniu. Planuje się utworzenie jeszcze dwóch poradni CEA w Katowicach i Wrocławiu, co zaspokoi zapotrzebowanie na profesjonalną opiekę psychologiczną w całym szkolnictwie artystycznym.

Głównym celem działalności SPPP CEA jest sprawowanie profesjonalnej opieki psychologicznej i pedagogicznej nad szeroko rozumianą społecznością szkół muzycznych, plastycznych i baletowych oraz burs szkolnictwa artystycznego w Polsce. Poradnie CEA urzeczywistniają ten cel przez działalność: a) poradnianą, b) integracyjno-superwizyjną, c) informacyjno-szkoleniową i d) publikacyjno-badawczą. Każdy rodzaj działalności obejmuje specyficzne formy pracy, które prezentuje tabela 1.

Tabela 1. Podstawowe formy działalności SPPP CEA

\begin{tabular}{|c|c|}
\hline $\begin{array}{l}\text { DZIALALNOŚĆ } \\
\text { PORADNIANIA }\end{array}$ & $\begin{array}{l}\text { a) konsultacje, } \\
\text { b) diagnozowanie, } \\
\text { c) opiniowanie, } \\
\text { d) pomoc terapeutyczna. }\end{array}$ \\
\hline $\begin{array}{l}\text { DZIALALNOŚĆ INTEGRA- } \\
\text { CYJNO-SUPERWIZYJNA }\end{array}$ & $\begin{array}{l}\text { a) spotkania zapewniające profesjonalne wsparcie dla psycho- } \\
\text { logów i pedagogów szkolnictwa artystycznego w poszczegól- } \\
\text { nych regionach, } \\
\text { b) udzielanie konsultacji specjalistom szkolnym z całego kraju. }\end{array}$ \\
\hline $\begin{array}{l}\text { DZIALALNOŚĆ INFORMA- } \\
\text { CYJNO-SZKOLENIOWA }\end{array}$ & $\begin{array}{l}\text { a) warsztaty dla uczniów, rodziców i nauczycieli, szczególnie } \\
\text { w szkołach, w których nie zatrudnia się specjalisty szkolnego, } \\
\text { b) ogólnopolskie seminaria i konferencje psychologiczno-pe- } \\
\text { dagogiczne. }\end{array}$ \\
\hline $\begin{array}{l}\text { DZIALALNOŚĆ PUBLIKA- } \\
\text { CYJNO-BADAWCZA }\end{array}$ & $\begin{array}{l}\text { a) zeszyty psychologiczno-pedagogiczne CEA, } \\
\text { b) monografie, raporty, artykuły, } \\
\text { c) projekty badawcze ogólnopolskie i regionalne. }\end{array}$ \\
\hline
\end{tabular}

Źródło: opracowanie własne. 
Działalność poradniana prowadzona jest głównie poprzez udzielanie konsultacji psychologicznych uczniom, nauczycielom i rodzicom. Bardziej szczegółowe treści konsultacji dotyczących kształcenia artystycznego zanalizowano w dalszej części artykułu. Istotną formę poradnictwa CEA stanowi diagnozowanie uczniów, które możliwe jest dzięki wyposażeniu poradni CEA w standaryzowane testy psychologiczne zarówno z obszaru metod diagnozy stricte psychologicznej (m.in. Test Matryc Ravena, TCT-DP - Rysunkowy Test Twórczego Myślenia Klausa K. Urbana i Hansa G. Jellena, CISS - Kwestionariusz Radzenia Sobie w Sytuacjach Stresowych Normana S. Endlera i Jamesa D.A. Parkera, Wielowymiarowy Kwestionariusz Samooceny MSEI Edwarda J. O'Briena i Samuela Epsteina), jak również diagnozy problemów dotyczących rozwoju artystycznego (m.in. Test Inteligencji Muzycznej Herberta D. Winga, Średnia Miara Słuchu Muzycznego Edwina E. Gordona, Test Twórczych Zachowań KANH Stanisława Popka). Wystawiane przez SPPP CEA opinie psychologiczne w coraz większym stopniu wpływają na codzienną praktykę kształcenia artystycznego, bowiem uwzględniony w nich został szeroki kontekst funkcjonowania artystycznego uczniów oraz sformułowane praktyczne zalecenia dla uczniów w zakresie uczenia się muzyki, plastyki i tańca, dla nauczycieli w zakresie nauczania przedmiotów artystycznych i dla rodziców w zakresie wychowywania dziecka uzdolnionego kierunkowo. Natomiast ostatnia forma działalności poradnianej pomoc terapeutyczna dla uczniów szkół artystycznych - nabiera w ostatnim czasie stale rosnącego znaczenia. W ramach sesji terapeutycznych psycholodzy CEA pracowali nad różnymi problemami wynikającymi z zaburzeń $\mathrm{w}$ funkcjonowaniu: poznawczym, emocjonalnym, osobowościowym, społecznym $\mathrm{i}$ artystycznym uczniów. Wykorzystywali przy tym metody terapeutyczne opracowane na podstawie technik poznawczo-behawioralnych, takich jak: kontrakt terapeutyczny, wywiad, analiza genezy problemów, skalowanie objawów, eksperyment behawioralny, systematyczna desensytyzacja, autoanaliza reakcji poznawczo-emocjonalnych, techniki modyfikacji myśli automatycznych i in.

Działalność integracyjno-superwizyjna służy udzielaniu profesjonalnego wsparcia psychologom i pedagogom szkolnictwa artystycznego dzięki specjalistycznym konsultacjom, a także organizowaniu w poszczególnych regionach regularnych spotkań, na których specjaliści szkolni mają okazję dzielić się refleksjami dotyczącymi mocnych i słabych stron wykonywanego zawodu. Najczęściej poruszane tematy to: opracowanie form współpracy między specjalistami w regionie, metodyka rozwiązywania problemów wychowawczych, formy i metody pomocy psychologiczno-pedagogicznej, poszerzanie umiejętności z zakresu stosowania testów zdolności muzycznych $\mathrm{i}$ in. $\mathrm{W}$ tych grupach powstaje również wiele wspólnych inicjatyw badawczych podejmowanych w regionach lub makroregionach, mających na celu diagnozowanie problemów z zakresu funkcjo- 
nowania psychicznego, wychowawczego i profilaktycznego uczniów w obszarze kształcenia muzycznego, plastycznego i baletowego.

Działalność informacyjno-szkoleniowa to udostępnianie, upowszechnianie i uprzystępnianie wiedzy psychologicznej oraz ćwiczenie kompetencji miękkich u uczniów, rodziców i nauczycieli szkół artystycznych. Ta aktywność z jednej strony polega na prowadzeniu warsztatów psychologicznych, szczególnie w szkołach, w których nie zatrudnia się specjalisty (zwykle są to szkoły muzyczne bez pionu ogólnokształcącego). Najczęstsze tematy to: Rola świadomości w procesie twórczym artysty; Jak z sukcesem wspierać ucznia w szkole muzycznej, czyli o roli rodziców i nauczycieli; ,, Oswoić treme” - warsztaty majace na celu przygotowanie psychofizyczne ucznia do występ; Bezpieczeństwo ucznia szkoły muzycznej; Postawy dorostych sprzyjajace procesowi edukacyjnemu w szkole muzycznej; Korzyści rozwojowe ucznia wynikajace z nauki w szkole muzycznej. Z drugiej zaś strony w ramach opisywanej działalności organizuje się ogólnopolskie przedsięwzięcia związane z problematyką psychopedagogiczną kształcenia artystycznego, takie jak: ogólnopolskie konferencje psychologiczno-pedagogiczne szkolnictwa artystycznego, ogólnopolskie warsztaty dla psychologów i pedagogów szkolnych szkolnictwa artystycznego, seminaria SPPP CEA dla dyrektorów szkół, nauczycieli, psychologów i pedagogów.

W ramach działalności publikacyjno-badawczej realizowane są regionalne i ogólnopolskie projekty badawcze, którym towarzyszy sporządzanie raportów, np. 1) Jakość programów wychowawczych oraz szkolnych programów profilaktyki realizowanych $w$ szkolnictwie artystycznym $w$ roku 2012/2013, 2) Diagnoza poczucia bezpieczeństwa uczniów ogólnokształcących szkół i burs artystycznych, 3) Diagnoza poziomu zagrożenia uzależnieniami i przemoca w szkolnictwie artystycznym $^{2}$. Opracowuje się również artykuły dotyczące różnych kontekstów edukacji artystycznej, pomocy psychologiczno-pedagogicznej oraz wychowawczych i profilaktycznych problemów szkolnictwa artystycznego, które publikowane są w ,Zeszytach Psychologiczno-Pedagogicznych Centrum Edukacji Artystycznej"3. W ramach działalności publikacyjno-badawczej powstają także monografie na temat szerokiego spektrum psychopedagogicznej problematyki kształcenia artystycznego ${ }^{4}$.

${ }^{2}$ Raporty dostępne są na stronie: www.ceaart.pl/publikacje-raporty-opracowania.

${ }^{3}$ Do chwili obecnej w Wydawnictwie CEA wydano trzy numery ,Zeszytów PsychologicznoPedagogicznych CEA" pod następującymi tytułami: Wybrane zagadnienia z zakresu problematyki wspierania ucznia oraz udzielania pomocy psychologiczno-pedagogicznej w szkołach artystycznych (nr 1, 2013), Konteksty edukacji artystycznej i pomocy psychologiczno-pedagogicznej (nr 2, 2014); Wychowawcza i profilaktyczna funkcja szkoty artystycznej (nr 3, 2015).

${ }^{4}$ Aktualnie w Wydawnictwie CEA trwają prace nad monografią Urszuli Bissinger-Ćwierz pt. Psychopedagogiczne metody pracy z uczniem najmłodszym i uczniem ryzyka dysleksji w szkole muzycznej. Poradnik dla nauczycieli klas instrumentalnych zawierajacy ponad 50 ćwiczeń i zabaw wspomagajacych grę na instrumencie. 
Osoby zainteresowane szczegółowymi danymi dotyczącymi wyżej opisanych form działalności SPPP CEA odsyłam do sprawozdania z roku 2014/2015, które znajduje się na stronie internetowej Centrum Edukacji Artystycznej ${ }^{5}$. Natomiast $\mathrm{w}$ dalszej części artykułu chciałabym dokonać syntetycznej analizy najczęściej odnotowywanych w praktycznej działalności poradnianej problemów dotyczących kształcenia artystycznego oraz odnieść je do kontekstów teoretycznych rozważań obecnych w wybranej polskiej i zagranicznej literaturze przedmiotu. Będzie to dobra egzemplifikacja współzależności teorii i praktyki. Z jednej strony bowiem problemy pojawiające się w literaturze przedmiotu mają swoje odzwierciedlenie w praktyce poradnianej, przez co praca psychologów CEA zyskuje zarówno swoje uzasadnienie teoretyczne, jak i poszerzenie zakresu metodycznego. Z drugiej zaś strony praktyka poradniana stanowi przyczynek do nowych opracowań teoretycznych, które wzbogacają wiedzę na temat funkcjonowania psychofizycznego uczniów szkół artystycznych.

\section{PROBLEMY ZWIĄZANE Z KSZTAŁCENIEM ARTYSTYCZNYM}

Wybrane - specyficzne tylko dla szkolnictwa muzycznego, plastycznego i baletowego - problemy zostały wyodrębnione na podstawie 70 sprawozdań psychologów CEA z okresu od września 2014 roku do czerwca 2015 roku. Problemy te można pogrupować w następujące kategorie: a) strategie radzenia sobie z tremą, b) techniki efektywnego ćwiczenia na instrumencie, c) inhibitory rozwoju artystycznego, d) budowanie zasobów osobowościowych i adekwatnej samooceny, e) wzmacnianie motywacji ucznia do nauki przedmiotów artystycznych, f) relacje uczeń-nauczyciel przedmiotu głównego. Szczegółowe treści dotyczące każdej kategorii, która stanowiła przedmiot konsultacji psychologicznych, ilustruje tabela 2.

Tabela 2. Konsultacje psychologiczne uczniów i nauczycieli dotyczące kształcenia artystycznego

\begin{tabular}{|l|l|}
\hline \multicolumn{1}{|c|}{$\begin{array}{c}\text { Problemy w zakresie } \\
\text { kształcenia artystycznego }\end{array}$} & \multicolumn{1}{c|}{ Treść konsultacji psychologicznych } \\
\hline $\begin{array}{l}\text { Efektywne strategie } \\
\text { radzenia sobie z tremą }\end{array}$ & $\begin{array}{l}\text { - analiza automatyzmów myślowych: a) w trakcie przygotowywania } \\
\text { się do występu, b) podczas trwania występu, c) po występie, } \\
\text { - restrukturalizacja kognitywna, kotwiczenie myślenia pozytywnego, } \\
\text { - ćwiczenia afirmacyjne, relaksacyjne (oddechowe, rozluźniające), } \\
\text { wizualizacja gry na scenie. }\end{array}$ \\
\hline
\end{tabular}

${ }^{5}$ Zob.: www.cea.art.pl/poradnictwo-psychologiczno-pedagogiczne. 


\begin{tabular}{|c|c|}
\hline $\begin{array}{l}\text { Techniki efektywnego } \\
\text { ćwiczenia na instrumencie }\end{array}$ & $\begin{array}{l}\text { - strategie myślenia i pracy mentalnej podczas gry na instrumencie, } \\
\text { - strategie pracy nad pamięcią muzyczną, } \\
\text { - znaczenie zaangażowania intelektualnego i emocjonalnego } \\
\text { w ćwiczeniu na instrumencie, } \\
\text { - wzmacnianie koncentracji uwagi poprzez świadome wykorzysty- } \\
\text { wanie pracy zmysłów: wzroku, słuch i dotyku, } \\
\text { - umiejętność zaplanowania pracy (wykonywania zadań): } \\
\text { a) jaki jest mój poziom zaawansowania ćwiczenia, b) jaki powinien } \\
\text { być mój poziom zaawansowania ćwiczenia, c) dlaczego nie ćwiczę } \\
\text { tak, jak powinnam/powinienem? d) co powinnam/powinienem } \\
\text { zrobić? } \\
\text { - opracowanie strategii ćwiczenia z wykorzystaniem technik } \\
\text { poznawczo-behawioralnych. }\end{array}$ \\
\hline $\begin{array}{l}\text { Rozpoznawanie czyn- } \\
\text { ników demotywujących } \\
\text { rozwój artystyczny }\end{array}$ & $\begin{array}{l}\text { - diagnoza przyczyn niepowodzeń i ukazanie mechanizmów } \\
\text { przyczynowo-skutkowych, } \\
\text { - wskazanie korzyści wynikających z kształcenia muzycznego, } \\
\text { - wypracowanie krótkoterminowych celów edukacyjnych, } \\
\text { - korekta harmonogramu dnia, ustalenie miejsca i czasu ćwiczenia, } \\
\text { - modyfikacja nawyków spędzania czasu wolnego, uczenie strategii } \\
\text { zarządzania sobą w czasie. }\end{array}$ \\
\hline $\begin{array}{l}\text { Wzmacnianie zasobów } \\
\text { osobowościowych ucznia } \\
\text { i podnoszenie jego } \\
\text { samooceny }\end{array}$ & $\begin{array}{l}\text { - podnoszenie poczucia wartości poprzez analizę własnych } \\
\text { zasobów, } \\
\text { - zwiększanie poczucia pewności siebie na podstawie określenia } \\
\text { osiągnięć, } \\
\text { - budowanie odporności psychologicznej w sytuacjach trudnych, } \\
\text { - wzmacnianie poczucia sprawstwa, } \\
\text { - ćwiczenie kompetencji miękkich, } \\
\text { - kształtowanie własnej tożsamości artystycznej. }\end{array}$ \\
\hline $\begin{array}{l}\text { Jak motywować uczniów } \\
\text { do nauki przedmiotów } \\
\text { artystycznych? }\end{array}$ & $\begin{array}{l}\text { - wskazywanie różnych form oddziaływania na motywację we- } \\
\text { wnętrzną i zewnętrzną, } \\
\text { - przy skrajnym zniechęceniu do nauki gry na instrumencie: analiza } \\
\text { sposobów aktywizacji z perspektywy nauczyciela, } \\
\text { - wskazanie nauczycielowi efektywnych technik organizacji czasu } \\
\text { ćwiczenia i czasu wolnego ucznia, } \\
\text { - wprowadzanie tablicy motywacyjnej. }\end{array}$ \\
\hline $\begin{array}{l}\text { Relacje interpersonalne } \\
\text { uczeń-nauczyciel } \\
\text { przedmiotu głównego }\end{array}$ & $\begin{array}{l}\text { - wskazywanie mechanizmów przyczynowo-skutkowych } \\
\text { w zachowaniach ucznia i nauczyciela, } \\
\text { - ćwiczenie wykorzystywania zasad komunikacji werbalnej } \\
\text { i niewerbalnej, } \\
\text { - wypracowywanie konstruktywnych strategii rozwiązywania } \\
\text { problemu: koleżeńska superwizja. }\end{array}$ \\
\hline
\end{tabular}

Źródło: opracowanie własne.

Trema i sposoby radzenia sobie ze stresem ekspozycyjnym zajmują od dawna pierwsze miejsce w rankingu specyficznych problemów szkolnictwa artystycznego, bowiem strach przed występem jest wręcz plagą polskiego szkolnictwa mu- 
zycznego (Machnikowska-Peschken 2014, s. 152) i dotyczy również szkolnictwa baletowego (Noremberg 2013, s. 73). Natomiast uczniowie szkół plastycznych radzą sobie z innym rodzajem stresu, który związany jest z oceną artystyczną i „kryzysem twórczości" (Olejniczak 2013, s. 61). W literaturze przedmiotu spotykamy liczne opracowania dotyczące tremy, zarówno o charakterze teoretycznym, jak i praktycznym. W teoretycznych artykułach znajdują się m.in.:

- definicje określające tremę jako stan towarzyszący ekspozycji społecznej związanej z elementami oceniania, presji czasu i braku możliwości poprawienia błędu, co ma miejsce w przypadku koncertu muzycznego i występu tanecznego (Kępińska-Welbel 2001, s. 204),

- opisy trzech rodzajów tremy - przedkoncertowej, koncertowej i pokoncertowej (Klickstein 2009, s. 136-140),

- kategoryzację symptomów tremy - fizjologicznych, poznawczych i behawioralnych (Hallam 2006, s. 102),

- identyfikację towarzyszących tremie lęków związanych z: 1) błędami pamięciowymi, 2) zbytnim napięciem psychofizycznym, 3) dezaprobatą społeczną, 4) poziomem umiejętności, 5) koncentracją myślenia na wykonaniu artystycznym (Lehrer 1987, s. 141-154).

Natomiast w artykułach o charakterze praktycznym podejmowana jest tematyka konkretnych strategii i sposobów radzenia sobie z symptomami tremy, takich jak: psychologiczne warsztaty pracy z tremą, relaksacja z elementami desensytyzacji, cztery kroki przygotowania do występów (Golicz, Sucharowska 2010, s. 135-142), trening sytuacyjny przed występem (Welc 2010, s. 155), etapy przygotowania się do występu: interpretacyjny, techniczny, mentalny/emocjonalny, fizyczny, organizacyjny (Klickstein 2009, s. 155). W The Musician's Way - nietłumaczonej na język polski książce Geralda Klicksteina, amerykańskiego profesora gitary z Uniwersytetu Artystycznego Północnej Karoliny - znajduje się bardzo wiele praktycznych podpowiedzi dotyczących przygotowania się do występu. Dobrym przykładem jest Inwentarz przed koncertem zawierający dokładnie rozpisane godzinowo etapy treningu osobistego (ćwiczenie, odpoczynek, posiłki, gimnastyka relaksacyjna, kontakt z innymi muzykami) i przygotowania logistycznego (nuty, instrumenty, strój, zegarek, woda, transport) (Klickstein 2009, s. 163). Sporządzenie takiego inwentarza może mieć dla każdego ucznia szkoły muzycznej wartość porządkującą, a przez to zwiększającą poczucie pewności siebie.

Jak łatwo zauważyć, problemy pojawiające się w literaturze przedmiotu znajdują swoje odzwierciedlenie w wyżej opisanej praktyce poradnianej szkolnictwa artystycznego. Podsumowując, można stwierdzić, że konsultacje psychologiczne prowadzone przez psychologów CEA w zakresie radzenia sobie z tremą mają na celu przede wszystkim zwiększenie samoświadomości ucznia w zakresie kontroli napięcia własnego ciała (relaksacja, oddech), odczuwanych emocji i sche- 
matów myślenia (kotwiczenie myślenia pozytywnego, ćwiczenia afirmacyjne) i wizualizacji (wyobrażanie sobie siebie grającego na scenie). Można rozszerzyć metodykę pracy poradnianej przez wprowadzenie praktyki osobistego i logistycznego przygotowania się do występu.

Drugim zagadnieniem, z którym spotkać się można tylko w szkołach muzycznych, jest problem świadomego i efektywnego ćwiczenia na instrumencie. Nie wszyscy muzycy, a szczególnie uczniowie szkół muzycznych, zastanawiają się nad tym, w jaki sposób ćwiczą i czy ich ćwiczenie przynosi zamierzone korzyści (Kaczmarek 2010, s. 161). Tymczasem samodzielna praca nad utworem stanowi najbardziej istotny etap w edukacji muzycznej. Bez systematycznego, konsekwentnego i świadomego ćwiczenia nie można w ogóle mówić o postępach. Uczeń wykonuje bowiem 95\% swej pracy bez nadzoru pedagoga. Lekcje są przede wszystkim po to, by zweryfikować umiejętności już opanowane oraz przyswoić wiadomości i zdobyć umiejętności nowe. Cały ciężar mozolnej, drobiazgowej pracy z instrumentem, wymagającej tysięcznych powtórek pojedynczych dźwięków, motywów, fraz, całych utworów, pokonywania problemów technicznych i interpretacyjnych, przerzucony jest na samodzielne ćwiczenie ucznia (Bissinger-Ćwierz 2010, s. 92). Psycholodzy CEA, znający specyfikę gry na instrumencie, potrafią pomóc uczniom zarówno w zakresie zaangażowania intelektualnego, emocjonalnego i sensorycznego podczas ćwiczenia, jak i strategii organizacji pracy własnej. Literatura przedmiotu również jest pomocna w tym zakresie. Na przykład Susan Hallam wymienia konkretne strategie ćwiczenia, takie jak: studiowanie samego zapisu nutowego, przegrywanie całego utworu bez zatrzymywania się, przegrywanie z zatrzymywaniem się w celu ćwiczenia poszczególnych części, wybieranie i ćwiczenie tylko określonych części (Hallam 2009, s. 27). Jednak najważniejsze jest, aby wiedzieć, na czym się skupić i jaki cel ćwiczenia osiągnąć. Jak wynika z tabeli 2, psycholodzy CEA, wykorzystując techniki poznawczo-behawioralne, strukturyzują ćwiczenie za pomocą następujących pytań: a) jaki jest mój cel ćwiczenia, b) jaki powinien być mój poziom zaawansowania ćwiczenia, c) dlaczego nie ćwiczę tak, jak powinnam/powinienem, d) co powinnam/powinienem zrobić? Z psychologicznego punktu widzenia ważne dla ucznia jest również, aby czynnie poprawiać tzw. bezpieczeństwo muzyczne, opracowując różne wejścia $\mathrm{w}$ utworze $\mathrm{w}$ przypadku powstania luk pamięciowych (Mornell 2009, s. 206). Wspominany już Klickstein zwraca uwagę na wartość ćwiczeń mentalnych w grze na instrumencie, czyli „przegrywanie” utworów w myśli i budowanie mentalnych „map utworu” (Klickstein 2009, s. 34-37). $\mathrm{Na}$ szczególne podkreślenie zasługuje też propozycja rozgrzewki przed ćwiczeniem (warming up), którą w polskich szkołach muzycznych praktykuje się rzadko albo wcale. A jest to o tyle istotne, iż przejście z rytmu dnia codziennego do ulotnej sfery muzyki wymaga specjalnego przygotowania ciała i umy- 
słu do gry na instrumencie. Rozgrzewka zawierająca elementy: oddechu, rozluźnienia mięśni, uświadomienia sobie celu ćwiczenia, koncentracji na dźwięku/frazie/utworze powinna poprzedzać każdą aktywność muzyczną (Klicksten 2009, s. 37-38). Tę technikę z powodzeniem można wykorzystywać i propagować w poradnictwie CEA.

Do udzielania efektywnej pomocy uczniom szkół artystycznych potrzebna jest duża wiedza na temat czynników demotywujących rozwój artystyczny, które często powodują zgłaszanie się uczniów i nauczycieli do SPPP CEA. Jedną z dróg do rozpoznania tych demotywatorów jest więc praktyka poradniana. Dużą część literatury przedmiotu stanowią opracowania autorstwa praktykujących psychologów i pedagogów szkolnych. Drugą drogą jest aktywność badawcza podejmowana w szkolnictwie artystycznym przez pracowników akademickich, która wnosi nowe spojrzenie na inhibitory rozwoju tanecznego, plastycznego i muzycznego. Okazuje się, że niepowodzenia w szkole baletowej najczęściej dotyczą przedmiotów ogólnokształcących, bowiem uczniowie-tancerze dość wcześnie precyzują swoją drogę zawodową, wkładając całą energię w naukę przedmiotów zawodowych. Inhibitorami specyficznymi dla samego rozwoju tanecznego są: przeciążenia fizyczne, kontuzje, zaburzenia w obszarze orientacji przestrzennej, koordynacji wzrokowo-ruchowej i pamięci kinestetycznej oraz niski poziom samodyscypliny i motywacji (Noremberg 2013, s. 75). W szkołach plastycznych naukę rozpoczynają uczniowie będący w rozwojowym okresie adolescencji, dla którego charakterystyczny jest bunt młodzieńczy polegający na aktywnym sprzeciwie wobec wszystkiego, co młody człowiek postrzega jako ograniczające, stwarzające zagrożenie niespełnienia idealistycznych oczekiwań lub niezgodne z nimi (Oleszkiewicz 2006, s. 63). Wyniki badań wskazują, iż charakter kształcenia plastycznego daje adolescentowi przestrzeń i narzędzia do konstruktywnego wyrażania siebie poprzez sztukę, co pozytywnie wpływa na obniżenie napięcia i zmniejszenie buntu młodzieńczego (Wroński 2014, s. 67-78). Nie można jednak zapomnieć, iż mimo ekspresyjno-projekcyjnej roli sztuki młodzież szkół plastycznych zagrożona jest uzależnieniami od papierosów i alkoholu, a w szczególności od narkotyków ${ }^{6}$. W literaturze przedmiotu obciążenia wynikające ze specyfiki kształcenia muzycznego są obszarem najszczegółowiej opracowanym. Podejmowane przez licznych autorów badania wskazują na różne inhibitory rozwoju muzycznego. I tak np. Ewa Kumik na podstawie badań własnych stworzyła hierarchię czynników demotywujących rozwój, którymi są kolejno: 1) stres spowodowany egzaminami i popisami, 2) ograniczenie czasu wolnego do minimum, 3) długie przebywanie w szkole, 4) nieporozumienia między nauczyciela-

${ }^{6}$ Dane z tego zakresu zamieszczone są w Raporcie CEA autorstwa Urszuli Bissinger-Ćwierz pt. Diagnoza poziomu zagrożenia uzależnieniami i przemoca $w$ szkolnictwie artystycznym. Raport $z$ ogólnopolskich badań ankietowych zrealizowanych $w 2014$ r., który dostępny jest na stronie: www cea.art.pl. 
mi, 5) niezdrowa ciągła rywalizacja, 6) alkoholizm nauczycieli (Kumik 2012). Ta ostatnia, szczególnie drażliwa kwestia, rzadko stanowi przedmiot badań w Polsce. Natomiast $\mathrm{w}$ innych krajach podejmowane są próby diagnozowania przyczyn nadużywania alkoholu wśród artystów, np. muzyków orkiestrowych w Wielkiej Brytanii (Dobson 2011, s. 240-260). Okazuje się, że picie alkoholu związane jest m.in. $\mathrm{z}$ byciem pod ciągłą presją oczekiwań związanych z działalnością artystyczną. Te oczekiwania towarzyszą zarówno dojrzałym muzykom, jak i uczniom szkół muzycznych, przyczyniając się do poczucia zmęczenia psychofizycznego. Do specyficznych przeciążeń doświadczanych przez uczniów zaliczamy również: a) przemęczenie wynikające $\mathrm{z}$ codziennego żmudnego ćwiczenia na instrumencie; b) niepokoje związane z publicznymi występami oraz obawy przed oceną słuchaczy i ekspertów muzycznych, które mają znaczący wpływ na samoocenę i poczucie własnej wartości; c) brak wsparcia i zrozumienia ze strony najbliższych, d) jawną i ukrytą artystyczną konkurencję między rówieśnikami (Gluska 2012, s. 65). Biorąc pod uwagę powyższe, należy stwierdzić, że pomoc psychologów CEA w zakresie przezwyciężania trudności uczniów szkół artystycznych koncentruje się głównie na: uświadamianiu przyczyn niepowodzeń i radzeniu sobie z nimi, uczeniu strategii zarządzania sobą w czasie, wypracowywaniu krótkoterminowych celów do osiągnięcia oraz wskazywaniu różnorodnych korzyści wynikających z kształcenia artystycznego.

Świadomość owych korzyści jest niezwykle istotna z punktu widzenia wzmacniania zasobów osobowościowych ucznia i podnoszenia jego samooceny, bowiem kształcenie artystyczne pełni ogromną funkcję ogólnorozwojową. Wspólnymi korzyściami, które wynosi z nauki każdy uczeń szkoły muzycznej, plastycznej i baletowej, są: a) w zakresie funkcji poznawczych - rozwój wiedzy i warsztatu pracy artystycznej, b) w zakresie funkcji rozwojowych - rozwój struktur mózgowych, usprawnianie aparatu gry, rozwój sensomotoryczny, zwiększanie elastyczności ciała, rozwój kinestetyczny, c) w zakresie funkcji wychowawczych - kształtowanie samodyscypliny, perfekcjonizmu, wytrwałości w podejmowaniu działań, umiejętności organizacji pracy, współdziałania i wzmacniania więzi społecznych, d) w zakresie funkcji ekspresyjno-kreatywnych - wyrażanie własnej osobowości poprzez sztukę, kontaktowanie się ze światem za pośrednictwem muzyki, plastyki i tańca, e) w zakresie funkcji motywacyjnych - podwyższony stan gotowości do dalszej pracy twórczej (por. Popek 2003, Żylińska 2013, Wojtanowska-Janusz 2014, Krygier 2014). W ramach poradnictwa CEA powstały dwie broszury ujmujące w syntetyczny sposób powyższą tematykę: Dlaczego warto ksztatcić się w szkole muzycznej? i Dlaczego warto ksztatcić się w szkole plastycznej? autorstwa Barbary Wojtanowskiej-Janusz i Magdaleny Krygier? Przyjmując szerszą perspektywę, należy stwierdzić, iż jakość spostrzegania otaczają-

${ }^{7}$ Obydwie broszury zamieszczone są na stronie: www.cea.art.pl/publikacje-raporty-opracowania. 
cego świata determinują mechanizmy osobowościowe człowieka. A zatem o powodzeniu w działalności muzycznej, plastycznej i tanecznej decydują nie tylko specyficzne zdolności kierunkowe, lecz także cała osobowość artysty-ucznia, w tym jego: potrzeby psychiczne, samoocena, postawy i poczucie wartości (Napora 2005, s. 249). Manturzewska stworzyła portret osobowościowy ludzi z wybitnymi osiągnięciami artystycznymi, którzy: a) są intelektualnie i emocjonalnie zafascynowani uprawianiem swojej dziedziny sztuki, b) koncentrują wszystkie siły psychiczne na pracy, c) nie zrażają się trudnościami, wytrwale i z uporem dążą do wykonywania zadań, d) są aktywni i chętni do podejmowania nowych wyzwań, e) są pewni swojego zdania i posiadają wewnętrzny układ odniesienia (Manturzewska 1980). Artyści ogólnie charakteryzują się wyjątkowo silną potrzebą twórczej ekspresji. Poziom owej ekspresji silnie koreluje z poziomem samozadowolenia, a ten z kolei jest podstawą samooceny. U artystów samoocena w głównej mierze opiera się na ocenie występów publicznych dokonywanej przez samego siebie lub przez ekspertów (Nogaj 2014, s. 52). Ponadto jako składnik motywacji zależy od: natężenia potrzeb, wartości celu i subiektywnego prawdopodobieństwa osiągnięcia sukcesu (Napora 2005, s. 253). Na tym głównie opiera się pomoc psychologiczna w ramach SPPP CEA, gdzie psycholodzy koncentrują się na: wzmacnianiu poczucia pewności i sprawstwa oraz budowaniu poczucia tożsamości artystycznej ucznia.

Najtrudniejszym zadaniem pedagoga, niezależnie od tego, jakiego przedmiotu artystycznego uczy - gry na instrumencie, wokalistyki, rysunku, malarstwa, rzeźby, tańca klasycznego, ludowego czy współczesnego - jest budowanie motywacji dzieci i młodzieży. Jak pisze Andrzej Janowski:

Jeśli chce się spowodować jakiekolwiek postępowanie u innych ludzi, to nie ma innej drogi, jak budzenie motywacji, ukazywanie perspektyw, dodawanie odwagi, jednym słowem spowodowanie, by człowiek sam zechciał uzyskać to, co dla niego dobre i by dla tej sprawy potrafił mobilizować samego siebie (Janowski 1980, s. 212).

Nadrzędny cel pracy pedagogicznej to rozwinąć samodzielność poznawczą ucznia, „dać uczniowi jak najszybciej takie gruntowne przygotowanie, aby pedagog przestał mu być potrzebny" (Neuhaus 1970, s. 31). W pedagogice artystycznej postrzega się nauczyciela jako mistrza, który ma nie tylko uczyć, ale także wychowywać, przede wszystkim przez bycie wzorem osobowym dla ucznia (Konaszkiewicz 2012, s. 62). Bowiem nauczyciel najmniej może przekazać za pośrednictwem tego, co mówi, jest w stanie więcej zdziałać tym, co robi, a najskuteczniej wpływa na wychowanków przez to, kim jest (Bissinger-Ćwierz 2008, s. 206).

Zaskakujące wyniki badań uzyskała Małgorzata Chmurzyńska. Wskazują one, iż większość obserwowanych nauczycieli szkół muzycznych „,zachowywała 
się w sposób świadczący o braku świadomości, że istnieje związek między ich postępowaniem a motywacją ucznia" (Chmurzyńska 2012, s. 323). A przecież liczne badania empiryczne dowodzą, iż oczekiwania nauczyciela bezpośrednio przekładają się na zachowanie ucznia. Badaczka sformułowała przy tym następujący wniosek: ,uczniowie zwykle osiągają takie rezultaty (pozytywne i negatywne), jakich oczekują od nich nauczyciele; uczeń, który osiąga lepsze rezultaty niż oczekuje nauczyciel, jest przez niego negatywnie oceniany" (Chmurzyńska 2012, s. 317). A zatem oczekiwania nauczyciela mają ogromny wpływ na osiągnięcia i motywację ucznia. Optymistyczne podejście do ucznia powoduje zwykle lepsze osiągnięcia artystyczne, a pesymistyczne nastawienie nauczyciela może zakłócić proces rozwoju artystycznego ucznia. Dodatkowo nadmierny krytycyzm nauczycieli i ich szczególna koncentracja na błędach pogłębiają demotywację wychowanków (Hallam 2006, s. 146). Natomiast czynnikiem, który bardzo intensywnie wyzwala potrzebę aktywności artystycznej u uczniów, jest emocjonalne zaangażowanie samego nauczyciela. Własna pasja artystyczna - muzyczna, plastyczna, taneczna - najskuteczniej „zaraża” ucznia. Jednak trudno powiedzieć, aby nauczyciele szkół muzycznych „zarażali” swoich uczniów, ponieważ zasadniczo podczas lekcji albo w ogóle nie grają, albo ograniczają się do demonstracji jedną lub obiema rękami krótkich fragmentów utworu, nie improwizują też ani nie grają dla przyjemności (Neuhaus 1970, Chmurzyńska 2012). Ponadto lekcje odbywają się w sposób schematyczny, zrutynizowany i nudny. Podczas obserwacji większości zajęć nie odnotowano jakichkolwiek prób zaktywizowania uczniów, urozmaicenia nauki w postaci zabaw muzycznych, zainteresowania uczestników różnymi możliwościami brzmieniowymi instrumentu (Chmurzyńska 2012, s. 316-333). Zwracanie uwagi nauczycielom na wyżej opisane mechanizmy przyczynowoskutkowe w zakresie motywowania uczniów do osiągnięć artystycznych należy do najważniejszych etapów pracy psychologów CEA.

W kontakcie z uczniami niezwykle istotne są relacje interpersonalne. Na owe relacje nauczyciel-uczeń obok osobowości samych uczniów największy wpływ mają osobista historia życia nauczyciela i jego dawne relacje ze swoimi nauczycielami. Problemy z przeszłości często projektowane są w mniej lub bardziej świadomy sposób bezpośrednio na uczniów (Hallam 2006, s. 177). Dlatego tak ważna jest ciągła praca nauczyciela nad samym sobą, nad kontrolą swoich uczuć, postaw i potrzeb. Stałe zwiększanie własnej samoświadomości osobistej i zawodowej pozwala na stawanie się pedagogiem refleksyjnym, który odpowiada sobie na następujące pytania: Kim jestem jako człowiek? Kim jestem jako pedagog? Jaki jest cel mojej pracy? W jakim kierunku podążam? Kogo uczę i wychowuję? W jaki sposób uczę i wychowuję? (Konaszkiewicz 2012, s. 49). Współczesna edukacja jawi się jako relacja dwóch równorzędnych podmiotów: ucznia i nauczyciela, lekcja zaś staje się miejscem spotkania, dialogu, gdzie dominują takie postawy, jak: cierpliwość, wyrozumiałość, ciepło emocjonalne, przyjazny stosunek i sympatia oka- 
zywana uczniowi (Kotusiewicz 2000, s. 17-22). Podstawą relacyjnego układu nauczyciel-uczeń są kompetencje psychologiczne pedagoga, m.in. w zakresie werbalnej i niewerbalnej komunikacji interpersonalnej. Tymczasem z badań Chmurzyńskiej wynika, iż większość nauczycieli-instrumentalistów ma znaczące braki w stosowaniu pozytywnych strategii komunikacyjnych, bowiem rzadko formułują pochwały, a jeśli już to robią, zwykle ograniczają się do ogólnikowych i zdawkowych („,no, nieźle”), natomiast przesadnie podkreślają błędy. Uwagi wypowiadane są często tonem ironicznym, w formie retorycznych pytań, z towarzyszeniem nerwowych ruchów i ciężkich westchnień. Ponadto, niezależnie od wieku ucznia, etapu kształcenia i zdolności, wszystkie uwagi od jednego nauczyciela są podobnie formułowane i dotyczą tych samych problemów, a bezpardonowe przerywanie gry ucznia oraz przekazywanie zbyt dużej liczby uwag i wskazówek staje się normą (Chmurzyńska 2012, s. 331-332). Można więc stwierdzić, że nauczyciele, prowadząc lekcje w tradycyjnej formule mistrz-uczeń, nie odczuwają potrzeby budowania z uczniem relacji partnerskich. Walka z tą tendencja stanowi główny przedmiot pracy psychologów SPPP CEA, którzy sugerują potrzebę organizowania koleżeńskich superwizji umożliwiających nauczycielom pozyskanie bezcennych informacji zwrotnych od innych kolegów-nauczycieli na temat poziomu swojej komunikacji z uczniem i atmosfery podczas lekcji.

\section{ZAKOŃCZENIE}

Głównym celem artykułu było wskazanie, iż specjalistyczne poradnictwo psychologiczno-pedagogiczne Centrum Edukacji Artystycznej stanowi istotną formę wsparcia psychologicznego, które otrzymują uzdolnieni uczniowie szkół artystycznych. Pośrednio wsparcie to możliwe jest dzięki działalności szkoleniowej, badawczej, publikacyjnej i superwizyjnej psychologów CEA, natomiast formę wspierania bezpośredniego stanowią działania poradniane. Pomoc w zakresie problemów doświadczanych w trakcie kształcenia muzycznego, plastycznego i baletowego dotyczy głównie radzenia sobie z tremą, efektywnego ćwiczenia, demotywatorów i sposobów motywowania do aktywności artystycznej, zasobów osobistych i relacji interpersonalnych uczeń-nauczyciel. Pomoc ta ma znaczenie nie tylko dla uczniów, ale również dla ich rodziców, a przede wszystkim dla nauczycieli. Bowiem to pedagodzy w głównej mierze odpowiedzialni są za jakość edukacji artystycznej. Im głębsza jest ich samoświadomości, tym lepszy staje się kontakt z uczniem, tym więcej wzajemnego szacunku, emocjonalnego wsparcia i osiągnięć artystycznych.

Ponadto należy podkreślić, iż rola nauczyciela, w tym pedagoga-artysty, we współczesnym świecie zmienia się zasadniczo. Każdy pedagog oprócz tradycyjnej roli nauczyciela, przekazującego w odpowiedni sposób określone wiadomości i umiejętności, pełni również funkcję wychowawcy. Niestety praktyka często wy- 
gląda tak, że nauczyciele przedmiotów artystycznych, przeciążeni pracą, koncentrują się głównie na sprawach dydaktycznych z pominięciem wychowawczych. Wydaje się, że ma to miejsce szczególnie w szkołach muzycznych i baletowych, w których dominuje nastawienie na efekty działania, często połączone z pewną nieuwagą, brakiem umiejętności i niechęcią wielu nauczycieli-artystów do skupienia się na szerszym, wychowawczym kontekście pracy uczniów.

Wychowanie wymaga czujności, zaangażowania, poszukiwania odpowiednich rozwiązań, a przede wszystkim daru ze swojego czasu. Jest jednak konieczne i nauczyciel, który zwalnia się z dbałości o sprawy wychowawcze w swojej pracy, sprzeniewierza się misji związanej z zawodem (Konaszkiewicz 2012, s. 63).

\section{BIBLIOGRAFIA}

Bissinger-Ćwierz U. (2008), Kompetencje zawodowe nauczyciela szkoły muzycznej w aspekcie psychologicznym, [w:] W. Limont, B. Didkowska (red.), Edukacja artystyczna a metafora, Toruń: Wydawnictwo UMK.

Bissinger-Ćwierz U. (2010), Emocjonalne funkcjonowanie uczniów szkót muzycznych, [w:] M. Manturzewska, B. Kamińska, A. Gluska (red.), Poradnictwo psychologiczne w polskich szkołach muzycznych, Warszawa-Bydgoszcz: Centrum Edukacji Artystycznej.

Chmurzyńska M. (2012), Kompetencje nauczyciela instrumentu. Stan pożądany-stan rzeczywisty, [w:] A. Michalski (red.), Tożsamość pedagogiki muzyki, Gdańsk: Wydawnictwo Athenae Gedanenses.

Dobson M. (2011), Insecurity, professional socialibilty and alcohol: Young freelance musicians 'perspectives on work and life in the music profession, „Psychology of Music”, vol. 39, 2, 240-260.

Gluska A. (2010), Charakterystyka pomocy psychologicznej w świetle trudności doświadczanych przez uczniów szkół muzycznych, [w:] M. Manturzewska, B. Kamińska, A. Gluska (red.), Poradnictwo psychologiczne w polskich szkołach muzycznych, Warszawa-Bydgoszcz: Centrum Edukacji Artystycznej.

Golicz M., Sucharowska Z. (2010), Opis warsztatu pracy z trema oparty na doświadczeniach muzyczka i psychologa, [w:] M. Manturzewska, B. Kamińska, A. Gluska (red.), Poradnictwo psychologiczne w polskich szkołach muzycznych, Warszawa-Bydgoszcz: Centrum Edukacji Artystycznej.

Hallam S. (2009), Jak nauczać, by uczenie się muzyki było skuteczne, [w:] B. Kamińska, M. Zagrodzki (red.), Ćwiczenie w rozwoju i działalności muzyka wykonawcy, Warszawa: Uniwersytet Muzyczny Fryderyka Chopina.

Hallam S. (2006), Music Psychology in Education, Londyn: Bedford Way Papers, UCL Institute of Education.

Janowski A. (1980), Psychologia społeczna a zagadnienia wychowania, Wrocław: WSiP.

Kaczmarek S. (2010), Efektywne sposoby ćwiczenia na instrumencie, [w:] M. Manturzewska, B. Kamińska, A. Gluska (red.), Poradnictwo psychologiczne w polskich szkołach muzycznych, Warszawa-Bydgoszcz: Centrum Edukacji Artystycznej.

Kępińska-Welbel J. (2001), Trema, [w:] M. Manturzewska (red.), Psychologiczne podstawy ksztatcenia muzycznego, Warszawa: Akademia Muzyczna im. Fryderyka Chopina.

Klickstein G. (2009), The Musician's Way. A Guide to Practice, Performance and Wellness, Nowy Jork: Oxford University Press. 
Konaszkiewicz Z. (2012), A. Michalski (red.), U podstaw pedagogiki muzycznej w perspektywie przeszłości i przyszłości, [w:] Tożsamość pedagogiki muzyki, Gdańsk: Wydawnictwo Athenae Gedanenses.

Kotusiewicz A.A. (2000), Pytanie o nauczyciela, [w:] A.A. Kotusiewicz (red.), Myśl pedeutologiczna i działanie nauczyciela, Białystok: Wydawnictwo Żak.

Krygier M. (2014), Korzyści wynikające z ksztatcenia w szkole plastycznej, „Zeszyty Psychologiczno-Pedagogiczne Centrum Edukacji Artystycznej”, 2, 59-65.

Kumik E. (2012), Postrzeganie środowiska szkolnego przez absolwentów szkół muzycznych, [w:] A. Michalski (red.), Tożsamość pedagogiki muzyki, Gdańsk: Wydawnictwo Athenae Gedanenses.

Lehrer P.M. (1987), A review of the approaches of the management of tension and stagefright in music performance, "Journal of Research in Music Education", 35 (3), 143-152.

Machnikowska-Peschken M. (2014), Czy można uzdrowić „, muzyczna schizofrenię”? - kilka uwag w sprawie ,Raportu o stanie szkolnictwa muzycznego I stopnia”, ,Zeszyty Psychologiczno-Pedagogiczne Centrum Edukacji Artystycznej”, 2, 149-154.

Manturzewska M. (1980), Rola cech osobowości w działalności muzycznej, [w:] Podstawy kształcenia muzycznego, t. II: Materiały pomocnicze dla nauczycieli szkót i ognisk artystycznych, Warszawa: Centralny Ośrodek Pedagogiczny Szkolnictwa Artystycznego, 21-31.

Manturzewska M., Kamińska B., Gluska A. (red.) (2010), Poradnictwo psychologiczne w polskich szkołach muzycznych, Warszawa-Bydgoszcz: Centrum Edukacji Artystycznej.

Manturzewska M. (1999), Tu się zaczęła nasza stużba, [w:] W. Jankowski, A. Zemła (red.), Pierwsza szkoła umuzykalniajaca w powojennej Warszawie, Warszawa: Wydawnictwo PSM I st. nr 1 im. Oskara Kolberga.

Mornell A. (2009), Ćwiczenie celowe i trzy stadia biegłości, [w:] B. Kamińska, M. Zagrodzki (red.), Ćwiczenie w rozwoju i działalności muzyka wykonawcy, Warszawa: Uniwersytet Muzyczny Fryderyka Chopina.

Napora E. (2005), Mechanizmy osobowościowe ucznia i ich związek z percepcja jakości obrazu nauczyciela, [w:] W. Limont, K. Nieledek-Zawadzka (red.), Dylematy edukacji artystycznej, t. I: Edukacja artystyczna wobec przemian w kulturze, Kraków: Oficyna Wydawnicza Impuls.

Neuhaus H. (1970), Sztuka pianistyczna. Notatki pedagoga, Kraków: Polskie Wydawnictwo Muzyczne.

Nogaj A. (2014), Rola cech osobowości w edukacji muzycznej z perspektywy psychologów, „Zeszyty Psychologiczno-Pedagogiczne Centrum Edukacji Artystycznej", 2, 47-54.

Noremberg J. (2013), Uwarunkowania osiagnięć edukacyjnych uczniów szkót baletowych, „Zeszyty Psychologiczno-Pedagogiczne Centrum Edukacji Artystycznej”, 1, 71-79.

Olejniczak E. (2013), Psychologiczne uwarunkowania rozwoju zdolności plastycznych u dzieci i młodzieży, „Zeszyty Psychologiczno-Pedagogiczne Centrum Edukacji Artystycznej”, 1, $41-44$.

Oleszkiewicz A. (2006), Bunt młodzieńczy. Uwarunkowania. Formy. Skutki, Warszawa: Wydawnictwo Naukowe Scholar.

Popek S. (2003), Człowiek jako jednostka twórcza, Lublin: Wydawnictwo UMCS.

Welc M. (2010), Znaczenie osoby pedagoga w ksztaltowaniu odpowiednich postaw i nawyków w zakresie technologii występu i postrzegania tremy przez uczniów w początkowej fazie nauki, [w:] M. Manturzewska, B. Kamińska, A. Gluska (red.), Poradnictwo psychologiczne w polskich szkołach muzycznych, Warszawa-Bydgoszcz: Centrum Edukacji Artystycznej.

Wojtanowska-Janusz B. (2014), Wpływ muzyki i edukacji muzycznej na rozwój dzieci i młodzieży, „Zeszyty Psychologiczno-Pedagogiczne Centrum Edukacji Artystycznej”, 2, 35-46.

Wroński R. (2014), Charakterystyka buntu młodzieńczego młodzieży uzdolnionej plastycznie, „Zeszyty Psychologiczno-Pedagogiczne Centrum Edukacji Artystycznej”, 2, 67-78.

Żylińska M. (2013), Muzyka w mózgu. Poradnik kieszonkowy CENSA, Warszawa: Centrum Edukacji Nauczycieli Szkół Artystycznych. 


\section{SUMMARY}

Significant form of psychological support for gifted students of music, visual-art and ballet schools is a specialized psychological and educational counselling Centre of Arts Education. A form of indirect support are information training and additional research action aimed at helping parents and teachers of art schools as well as integration-supervisory action aimed at supporting educational specialists of artistic schools. In contrast, psychological and educational counselling is a form of direct support for students in solving specific artistic education-related problems: coping with stage fright, effective exercises for an instrument, motivating factors and inhibitors of artistic development, personality and self-esteem resources, student-teacher interpersonal relations. These problems were presented in a broad context of theoretical considerations present in Polish and foreign literature.

Keywords: counselling CAE; music, visual-art and ballet schools; psychopedagogical problems of artistic education 